\title{
Vegetable Stain as an Alternative to H\&E in Exfoliative Cytology
}

Sherin Singnarpi ${ }^{1 *}$, Pratibha Ramani ${ }^{2}$, Anuja Natesan ${ }^{2}$, Herald J Sherlin², Gheena S², Giffrina ${ }^{2}$, Abhilasha², Don ${ }^{2}$ and Archana ${ }^{2}$

${ }^{1}$ Oral Pathology, Saveetha Dental College, Saveetha University, 162, Poonamalee High Road, Vellapanchaavadi, Chennai, Tamil Nadu 600077, India

${ }^{2}$ Oral and Maxillofacial Pathology, Saveetha Dental College and Hospital, Chennai, Tamil Nadu 600077, India

\begin{abstract}
Experimentally red beet additionally referred to as beet root (Beta vulgaris L.) used as vegetable stain.

Objective: To organize a dye extract from beet root to stain the buccal smear as substitution low cost and simple obtaining material.

Material and method: Collected buccal smear from patient in Saveetha dental faculty around ten buccal smears every and glued in alcohol for half-hour. Then the staining was finished beet root extract answer.

Results: The cells were stained brown in color with beet root. This study showed that the preservation of cellular morphology was gift and clarity of cellular details was moderate. Additionally showed delicate staining uniformity and background staining was gift.
\end{abstract}

Conclusion: Beet root is accustomed stain buccal smear in exfoliative microscopic anatomy.

Keywords: Beet root; Oral buccal smears; Vegetable stain

\section{Introduction}

The emergent need and campaign of the international agencies in promoting greener and cleaner environment should urge different agencies including clinical laboratories in using safe and environment friendly chemicals. The urgency leads to develop safe, non-toxic and organic stain. The beet root (Beta vulgaris) plant belongs to chenopodae family. Usually known as the beet, also red beet or golden beet. It is one of the several of cultivated varieties grown for their edible taproots and their leaves. The Beta vulgaris have advantage in medicine such as it had a strong lipotropic and antioxidant effect inside human body. Furthermore been revealed the red beet appeared as inhibitor effect in lung and skin tumor produced the Epstein-Barr virus experimented in vivo [1-8].

The beet root contains different substantial elements like amino acid, sucrose, minerals, vitamins and dyes in fruit and roots. In addition the beet root has been used as natural colorant in food costumers which it could be healthier or at least not harmful [1].

The aim of the study include prepare dye extract from beet root to stain the oral smear in exfoliative cytology as substitution cheap and easy getting material.

\section{Materials and Methods}

Twenty oral smears were collected from in patient in Saveetha Dental College each and fixed in alcohol for 30 minutes. One each was kept for H\&E staining and the other for beet root staining. For beet root staining the following method was followed:

1. Extract solution from beet root: the plant of beet root were cut to small portion and boiled set to filtration.

2. The alcohol fixed buccal smears were then transferred to beet root solution and kept for 1-2 days.

3. $3.70 \%$ ethanol for 15 minutes to wash out excess stain.

4. Placed the specimen in acid alcohol ( $2 \mathrm{ml}$ of concentrated HCL in $100 \mathrm{ml}$ of $70 \%$ alcohol) in order to remove excessive stain without loss of pigmentation.
5. The specimen was transferred to $90 \%$ ethanol for 30 minute and dehydrates in grades of alcohol.

\section{Results}

Through the picture (Figures 1 and 2) under the microscope the samples were evidently stained by red beet extract and have well defined structure. The staining intensity was similar of $30 \%$ beet root to $30 \% \mathrm{H} \& \mathrm{E}$. The preservation of cellular morphology was $44 \%$ seen in beet root and $45 \%$ in H\&E. The background staining was almost seen similar $6 \%$ in beet root and $5 \%$ in H\&E. The clarity of cellular details was seen more in H\&E than beet root.

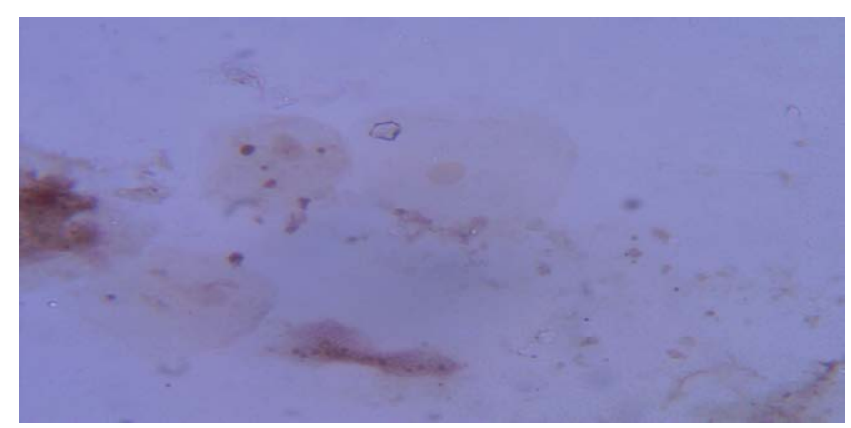

Figure 1: In 40x view: cells are seen.

*Corresponding author: Singnarpi S, Student, Post Graduate, Saveetha University Saveetha Dental College, Oral pathology, 162, Poonamalee High Road, Vellapanchaavadi, Chennai, Tamil Nadu 600077, India, Tel: +919841942967; E-mail: Sherinsingnarpi@rocketmail.com

Received February 13, 2017; Accepted August 13, 2017; Published August 20 2017

Citation: Singnarpi S, Ramani P, Natesan A, Sherlin HJ, Gheena S, et al. (2017) Vegetable Stain as an Alternative to H\&E in Exfoliative Cytology. J Cytol Histol 8: 469. doi: $10.4172 / 2157-7099.1000469$

Copyright: (c) 2017 Singnarpi S, et al. This is an open-access article distributed under the terms of the Creative Commons Attribution License, which permits unrestricted use, distribution, and reproduction in any medium, provided the original author and source are credited. 
Citation: Singnarpi S, Ramani P, Natesan A, Sherlin HJ, Gheena S, et al. (2017) Vegetable Stain as an Alternative to H\&E in Exfoliative Cytology. J Cytol Histol 8: 469. doi: 10.4172/2157-7099.1000469

Page 2 of 2

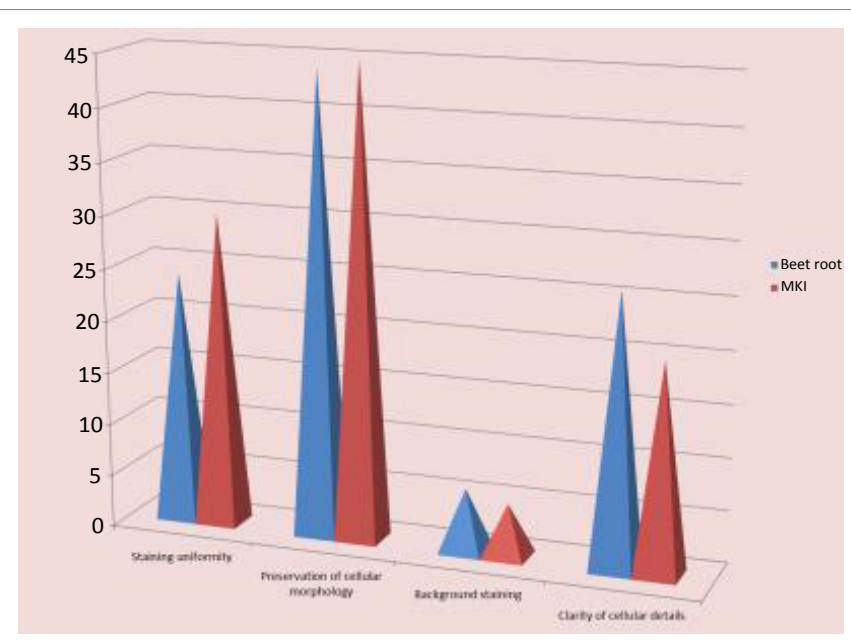

Figure 2: The graph represents the percentage of beet root and H\&E stain.

\section{Discussion}

The beet root belongs to the chenopadae family (Beta vulgaris). In our day to day life everything we are dealing with is inorganic, so, we are trying to make an organic dye which is least harmful and safe for the environment. The staining intensity of beet root was $30 \%$ and is similar to H\&E. Mohanad et al. in his study stated that the specimen was successfully stained in tissues of helminthes.

The preservation of cellular morphology was $44 \%$ seen in beet root and $45 \%$ in H\&E. The background staining was almost seen similar $6 \%$ in beet root and 5\% in H\&E. The clarity of cellular details was seen more in $\mathrm{H} \& \mathrm{E}$ than beet root.

Gasztonyi et al. also in his study stated that betacyanin was responsible for the stain pigment which was red in color. It is a cytoplasmic stain and the betacyanin (red color) is acidic in nature and can be used in placed of eosin. From our study we concluded that beet root can also be used in staining in exfoliative cytology.

\section{Conclusion}

Based on the study conducted the dye that is produced from Beta vulgaris can stain the cells. From all above mention the regard red beet extract or its juice has prosperous stain for pigmentation as natural dye material that it would be cheap dye than expensive artificial one and capable to developed.

\section{References}

1. Al-Adreesy SR (2005) A comparative study between commercial acid carmin and watery extract of kujarat flowers (Hibiscus sabdariffa) for staining some helminthes parasites. Al-Qadisiya J Vet Sci 2: 69-76.

2. Al-Azizz ZAAA (2010) The use of some natural dyes for detection of viability of Echinococcus granulosus protoscolices in vivo. Minufiya Vet J 7: 433-439.

3. Al-Kubaasy E (2004) Dictionary of grass and medicine plants. Dar Al-Kotob Alllmiyah Beirut, 566.

4. Boris N, Zbigniew P, Aneta P, Pawel S, Wayne T, et al. (2011) Betalainic and Nutritional profiles of pigment - enriched red beet root. Food Chemistry 127 42-53.

5. Daryani A, Sharif M, Meigouni M (2010) Staining of Fasciola hepatica by natural herbal dyes. Comparative Clinical Pathology 20: 305-308.

6. Gasztonyi MN, Daood H, Hajos MT, Biasc P (2001) Comparison of red beet (Beta vulgaris var. conditiva) varieties on basic of their pigment component. $J$ Sci Food \& Agri 81: 932-933.

7. Govind J, Kapadia A, Harukuni T, Takao K, Hoyoku N (1996) Chemoprevention of lung and tumor skin cancer by Beta vulgaris (beet) root extraction. Cancer Letter 100: 211-214.

8. Adriana PV, Cachita CD, Pop L, Purcarea C (2010) Histo-anatomical specific feature of red beet and sugar beet vitro plantlets Fascicula: Protectia mediului. Bas J Vet Res 11: 740-748. 